\title{
A survey of Indian logic from the point of view of computer science
}

\author{
V V S SARMA \\ Department of Computer Science \& Automation, \\ Indian Institute of Science, Bangalore 560012, India
}

\begin{abstract}
Indian logic has a long history. It somewhat covers the domains of two of the six schools (darsanas) of Indian philosophy, namely, Nyaya and Vaisesika. The generally accepted definition of Indian logic over the ages is the science which ascertains valid knowledge either by means of six senses or by means of the five members of the syllogism. In other words, perception and inference constitute the subject matter of logic. The science of logic evolved in India through three ages: the ancient, the medieval and the modern, spanning almost thirty centuries. Advances in Computer Science, in particular, in Artificial Intelligence have got researchers in these areas interested in the basic problems of language, logic and cognition in the past three decades. In the 1980s, Artificial Intelligence has evolved into knowledge-based and intelligent system design, and the knowledge base and inference engine have become standard subsystems of an intelligent system. One of the important issues in the design of such systems is knowledge acquisition from humans who are experts in a branch of learning (such as medicine or law) and transferring that knowledge to a computing system. The second important issue in such systems is the validation of the knowledge base of the system i.e. ensuring that the knowledge is complete and consistent. It is in this context that comparative study of Indian logic with recent theories of logic, language and knowledge engineering will help the computer scientist understand the deeper implications of the terms and concepts he is currently using and attempting to develop.
\end{abstract}

Keywords. Indian logic; logic; language; artificial intelligence; cognition.

\section{History}

Mahamahopadhyaya Satis Chandra Vidyabhusana in his monumental work on the history of Indian Logic considers three principal phases of developments: The ancient school of Indian logic with the representative text, Nyaya Sutra of Gautama (650 B.C. - 100 A.D.), the Medieval school of Indian logic with the representative 
text, Pramana Samuccaya of Dignaga (100 A.D. - 1200 A.D.) and the modern school with the representative text, Tattva Cintamani of Gangesa (900 A.D. onwards). The Hindus and the Greeks have developed their logical systems largely independent of each other. It is conceiveble that the notion of a syllogism developed by Aristotle in his Rhetoric might have found its way to India. It has been said that sage Narada visited Svetadvipa (Alexandria) and became an expert in the handling of the five limbed syllogism. (Chandra Vidyabhusana, 1921).

Anviksiki started as the science of inquiry and has grown into the art of debate. It had its beginnings in the Atma Vidya or Brahma Vidya (science of the soul or the divine science) pursued by the Upanisads. Anviksiki differed from Atma Vidya as it dealt with two subjects: atma, the soul and hetu, the theory of reasons. It later bifureates into philosophy and logic. In the former aspect, it evolved into darsana and in the later aspect it evolved iuto hetu vidya (the science of reasoning ) or tarka mdya (the art of dobate). Anviksiki las been held in high esteem in works such as Kautilya's Artha sastra.

The technical terms of anviksiki may be found in books such as Aitareya Brahmana, and Kathopanishad. One can visualise a council conducting debates of learned men (Stamsad, samiti, sabha or paratad), where discussions on true knowledge wert taking place in the context of four valid means of obtaining the sanc:

1. Simvte (scripture);

2. Pratyaksha (perception);

3. Aitihya (tradition);

4. Anumana (inference).

\section{The ancient school}

Indian logic by itself is a very vast subject. 'The ancrent Sanskrit torm. Nyaya, probably was used initially in a more general sense. Vaisesika is often considered the sister science (sastra) of Nyaya. The purpose of Indian logic has been to acquire valid knowledge through perception aud inference.

The Nyaya sutras are associated with Aksapada (iautana. The five books on Nyaya deal with the following:

1. Sixteen categories of the system;

2. Doubt, the four means of proof and their validity:

3. The self, the body, the senses and their objects, the mind and cognition:

1. Theory of error and of the whole and its parts; and

5. Thureal objections and occasions for rebuke of an opponent.

'The Vaisesika works are traced to Kanada. These deal with, anong other things.

1. The five categories: substance, quality, motion, generality and particularity;

2. The five elements: earth, water, fire, air, ether and space and time: 
3. Objects of sense, the self, the mind and the theory of inference;

4. Perception;

5. Causality ;

6. The atomic theory, the self and inherence.

While sciences such as astronomy, geometry and philology have arisen in close connection with the sacricificial rituals of Vedas, Nyaya probably arose in the context of the Mimamsa. Anviksiki as the name of a science appears in Gautama Dharma Sutra beside the Vedic science (trayi). By means of this Vyasa is said to have arranged the Upanisads as recorded in the Mahabharata. Anviksiki has been treated as a subject of study suitable for a king. It was probably applied to secular ends such as justice apart from being applied to sacred things. It was probably the reason why Anviksiki was censured in the Ramayana, as its wrong application was leading men towards not following the prescriptions of the Dharmacastras.

Sage Narada is described as skilled in Nyaya, able to distinguish unity and plurality, conjunction and inference, priority and posteriority, deciding matters by means of proof, and a judge of the merits and demerits of a five-membered syllogism. Caraka in his medical Samhita gives a sketch of some of the Nyaya principles, and of the Vaisesika categories, in such a way as to indicate that he regarded the systems as supplementing each other. In the earlier grammatical literature, Panini, Katyayana and Patanjali know the meaning of Nyaya as conclusion but show no trace of recognizing a Nyaya system.

\subsection{Knowledge}

Aksapada Gautama says in his Nyaya Sutras that supreme felicity is obtained by the knowledge of the sixteen categories treated in his work:

1. The neans of right knowledge (pramana)

Perception (pratyaksa) inference (anumana), comparison (upamana) and word or verbal testimony ( $s a b d a)$ are the means of right knowledge.

(a) Perception is the knowledge which arises from the contact of a sense with its object, being unnameable, determinate and nonerratic.

\begin{tabular}{|l|l|}
\hline $\begin{array}{l}\text { Un-nameable } \\
\text { avyapadesyam }\end{array}$ & $\begin{array}{l}\text { Signifies that the knowledge of a thing } \\
\text { derived through perception has no connection } \\
\text { with the name the thing bears }\end{array}$ \\
\hline $\begin{array}{l}\text { Deterministic } \\
\text { vyavasayath- } \\
\text { makam }\end{array}$ & $\begin{array}{l}\text { This distinguishes perception from uncertain } \\
\text { knowledge (from a distance a man cannot } \\
\text { distinguish between dust and smoke) }\end{array}$ \\
\hline $\begin{array}{l}\text { Nonerratic } \\
\text { Avyabhicari }\end{array}$ & $\begin{array}{l}\text { Man is prone to visual illusions. } \\
\text { In summer, one may see water far away } \\
\text { in a mirage, when there is no water. }\end{array}$ \\
\hline
\end{tabular}

There is thus a need to establish the validity of the knowledge obtained through perception Pramanya vada. Prama stands for valid knowledge, while aprama or bhrama stand for invalid knowledge. 
(b) Inference is knowledge which is preceded by perception and can be $a$ priori, a posteriori or commonly seen.

Gautama lays down that there are five members (avayava) of a syllogism, namely,

i. proposition (pratijna),

ii. reason (hetu),

iii. example (udaharana),

iv. application (upanaya),

v. conclusion (nigamana).

The scheme of Gautama is illustrated by the syllogism:

The hill is fiery.

Because it has smoke.

Whatever is smoky is fiery, like a kitchen.

So is the hill (smoky).

Therefore, the hill is fiery.

(c) Comparison is the knowledge of a thing through its similarity to another thing which is previously well known. This is often called "Learning by Analogy" in AI literature.

(d) Verbal 'Testimony or Word ( $s a b d a$ ) is the instructive assertion of a reliable person. Learning from an expert (Knowledge Acquisition) in a modern day expert system like MYCIN (a computer program for diagnosing and prescribing treatment of infectious diseases) is often done by the knowledge engineer interviewing an expert and noting his situation - action behaviour, and representing it as an IF-TIIEN rule (Rich, 1985).

2. The object of right knowledge (praineya). Soul (atma); body (sarira); senses (indriya) inose, tongue, eye, skin. ear; intellect (buddhi); mind (manas) and some others are listed under this.

3. Doubt (samsaya) is a conflicting judgment about the precise character of an object.

4. Purpose (prayojana).

5. Example (drstanta).

6. Tenet (siddhanta).

7. Members (avayava).

8. Confutation (larka).

9. Ascertainment (nirnaya).

10. Discussion ( vada) is the adoption by two parties of two opposite theses, which are each analysed in the form of the five-membered syllogism, and are supported or condemned by any of the means of right knowledge, and by confutation without deviation from the established tenets. The objective of discussion is seeking the truth. 


\section{Example:}

Discutient (D): There is soul.

Opponent (O): There is no soul.

D: Soul is existent (proposition).

Because it is an abode of consciousness (reason).

Whatever is not existent is not an abode of consciouness, as a hare's horn (negative example).

Soul is not so, that is soul is an abode of consciouness (negative application). Therefore, soul is existent (conclusion).

O: Soul is nonexistent (proposition).

Because it is not perceptible by any of the senses (reason).

Whatever is not perceptible by any of our senses is not existent as a hare's horn (positive example).

Soul is so (is not perceptible by any of our senses) (positive example).

Therefore soul is nonexistent (conclusion).

D: The scripture which is a means of right knowledge declares the existence of soul.

O: The scriptures (of certain sects) deny the existence of soul.

11. Wrangling (jalpa) aims at gaining victory by resorting to quibbles, analogues and processes which deserve rebuke.

12. Cavil (vitanda) consists of mere attacks on the arguments of the opponent.

13. Fallacies (hetvabhasa) of reason are the erratic (savyabhicara), the contradictory (viruddha), the controversial (prakarana sama), the counter questioned (sadhya sama) and the mistimed (kalatita).

Examples:

Sound is noneternal (proposition). Because it is not possessed of the attribute of eternality (reason).

The reason does not throw any new light.

14. Quibble (chala).

15. Analogue (jati).

16. The point of defeat (nigrahosthana).

Vatsyayana, author of Nyaya Bhashya, one of the many commentaries of the Nyaya Sutra (A.D. 400), reveals that there were others who raised the number of members of the syllogism to ten. They are the desire to know (jijnasa), the doubt (samcaya), the belief in the possibility of a solution (cakyaprapti), the purpose in view in attaining the solution (prayojana), the removal of doubt (samcaya-vyudasa).

With its full ten members, we have before us in miniature, the course of the kind of discussions which preceded the development of the logical process, and we can recognize the substantial progress achieved in omitting all that did not directly bear on the attainment of a conclusion. 
Note that a modern Artificial Intelligence text typically talks briefly only of Aristotle's three-membered syllogism involving logical deduction (modus ponens) (Rich 1985).

Example:

All men are mortal.

Socrates is a man.

Therefore, Socrates is mortal.

While deduction is a perfectly valid proof, real life systems do not permit its use excepting in applications such as mathematical theorem proving. In a real life system such as medical diagnosis or pattern recognition, one has to be content with reasoning techniques such as induction and abduction. Induction involves generalisation from examples and abduction provides a plausible explanation.

\section{The medieval school}

Buddhist philosophers Nagarjuna (250-300 A.D.) and Maitreya (400 A.D.) use threemembered syllogisms:

1. The hill is full of fire.

2. Because it is full of smoke.

3. That which is full of smoke is full of fire, as a kitchen.

Vasubandhu (about 450 A.D.) omits the example and gives his syllogism as fol lows:

1. The hill is full of fire.

2. Because it is full of smoke.

3. All that is full of smoke being full of fire.

Buddhist logician Dignaga (450-520 A.D.) is considered to be the greatest logician India has ever produced. He was born in Kancheepuram, lived in Vengi desa (present West Godavari District, A.P.) and later probably travelled north. He had several works to his credit such as Pramana Samuccaya, Nyaya Pravesa, and Hetu Cakra Samarthana. Most of the works of Buddhist logicians of this age are avilable only in Tibetan.

Pramana Samuccaya, begins thus:

Bowing down before Sugata, the teacher and protector of the world, I, for the sake of expounding valid knowledge (pramana), put together here various scattered matters, compiled from my own works. The book has six chapters entitled

1. Perception (pratyaksa).

2. Inference for own self (svarthanumana). 
3. Inference for the sake of others (pararthanumana),

4. Reason and Example (hetu, drstanta),

5. Negation of oppposite (apoha),

6. Analogue (jati).

Dignaga notes that demonstration and refutation, together with their fallacies, are useful in arguing with others while perception and inference together with their fallacies are useful for self understanding.

\begin{tabular}{|c|c|c|c|c|}
\hline $\mathrm{S}$ & $P$ & $\mathrm{R}$ & E1 & E2 \\
\hline Subject & Predicate & $\begin{array}{l}\text { Reason } \\
\text { or mark }\end{array}$ & Example 1 & Example 2 \\
\hline $\begin{array}{l}\text { A minor } \\
\text { term } \\
\text { paks } a \\
\text { or } \\
\text { dharmin }\end{array}$ & $\begin{array}{l}\text { A major } \\
\text { term } \\
\text { sadhya } \\
\text { or } \\
\text { dharma }\end{array}$ & $\begin{array}{c}\text { A middle } \\
\text { term } \\
\text { hetu or linga } \\
\text { or } \\
\text { sadhana }\end{array}$ & $\begin{array}{c}\text { drstanta } \\
\text { homoge- } \\
\text { neous } \\
\text { sadharmya } \\
\end{array}$ & $\begin{array}{c}\text { drstanta } \\
\text { hetero- } \\
\text { geneous } \\
\text { vaidharmya }\end{array}$ \\
\hline
\end{tabular}

The form of syllogism is as follows:

1. This hill (S) is fiery $(\mathrm{P})$.

2. Because it has smoke $(\mathrm{R})$.

3. All that has smoke is fiery, like a kitchen (homogeneous example, E1) and whatever is not fiery has no smoke, like a lake( heterogeneous example, E2).

A proposition offered for proof is a thesis. The following are some of the fallacies of the thesis.

1. A thesis incompatible with perception. (e.g. Sound is inaudible.)

2. A thesis incompatible with inference. (e.g. A pot is eternal. In reality, it is noneternal because it is a product.)

3. A thesis incompatible with public opinion. (e.g. Money is an abominable thing. While some saints may hold this opinion, the world does not say so. In fact, it says Dhana mulam idam jagat.)

4. A thesis incompatible with one's own belief or doctrine. (e.g. A Vaisesika philosopher saying that sound is eternal.)

5. A thesis incompatible with one's own statement. (eg. My mother is barren.) 
Another great logician of this school is Dharmakirti (around 650 A.D.). His works include Pramana Vartika Karika and Nyaya Bindu. His definition of perception as a source of valid knowledge is an improvement over the ones in the earlier age. While valid knowledge can be acquired through senses, Dharmakirti says, it should be free from preconception (kalpana) and devoid of error (abhranta). For example, in darkness a rope might appear as a snake, and for a person moving in a boat, trees on the bank may appear to be moving in the opposite direction. In other words, these logicians were very much concerned with uncertainty in human knowledge, which incidentally is a major research issue in modern day knowledge system design. Dharmakirti also discusses the requirements of the middle term smoke in the context of svarthanumana.

1. 'The hill has fire.

2. Because it has smoke.

3. Like a kitchen, but unlike a lake.

\subsection{Jaina logic}

Apart from Buddhist scholars, Jaina scholars also have contributed significantly to logic in this period. In the Jaina scriptures, Sthananga-sutra and Bhagavati-sutra, there is classification of valid knowledge as pramana, pamana, jnana, nana or hetu. When hetu is used in the sense of inference, it is classified according to the following types:

1. This is because that is: There is a fire, because there is smoke.

2. This is not because that is: It is not cold, because there is a fire.

3. This is because that is not: It is cold here, because there is no fire.

4. This is not because that is not: There is no simsupa tree here, because there are no trees at all.

Bhadrabahu, in his Sutra-krtanga niryukti, mentions another principle of the Jaina logic called Syadvada, or the assertion of possibilities. The Syadvada is set forth as follows:

1. May be, it is.

2. May be, it is not.

3. May be it is, and it is not.

4. May be it is indescribable.

5. May be it is, and yet is indescribable.

6. May be it is not, and yet is indescribable.

7. May be, it is and it is not and it is indescribable. 


\section{The modern age of Indian logic}

Gangesa Upadhyaya of Mithila of 12 th century is a key figure representing the modern Indian school of logic. He is the author of Tattva Cintamani, which consists of four books dealing respectively with perception (pratyaksa), inference (anumana), comparison (upamana) and verbal testimony (sabda), which are the four means of obtaining valid knowledge.

\subsection{Perception}

Gangesa in the book I of Tattva cintamani distinguishes between ordinary perception (laukika pratyaksa) and transcendental (alaukika pratyaksa). The latter, in turn, may be having samanya laksana, jnana laksana or yogaja laksana corresponding to ordinary or enlightened (or transcendental) characteristics.

The ordinary perception is of six kinds:

1. Union (samyoga): In the visual perception of a jar or chair, there is a union of the eye of the observer with the object called a jar or a chair.

2. United-inherence (samyukta-samavaya): When we see a jar, we also see its colour, which is an inherent attibute of the jar.

3. United-inherent-inherence (samyukta-samaveta-samavaya): When we see jar, we see its colour and also the concept or notion of an object having a colour.

4. Inherence (samavaya): Sound is inherently perceived by our ears.

5. Inherent-inherence (samavetha-samavaya): The soundness of sound is also perceived.

6. Particularity (visesanata): Perception of nonexistence of a jar when a jar is not there.

The sense through the instrumentality of which we perceive colour is the eye. Similarly, we perceive sound with the ear and smell with the nose. These are examples of external senses. The sense which operates as an instrument, in our perception of pleasure, pain, desire, averice, intellect and volition is the MIND, which is called the internal sense. It is called atomic, since it can perceive objects one at a time. (e.g. The object is perceived either as a snake or a rope at a time.)

One can also distinguish between immediate perception and mediate or reflective perception.

Example:

This is a pot.

I know this is a pot.

$I$ know this object is a pot as I can perceive its potness.

\subsection{Inference}

The second chapter of Gangesa's book deals with inference (anumana khanda).

Gangesa agrees that inference is one of the means of generating knowledge (anumitinirupana). The most interesting contribution in his work on inference is the doctrine of invariable concomitance (vyapti). It has been described variously as pervasion, inseparable connection, perpetual attendance or constant copresence.

There are five provisional definitions for this doctrine (vyapti panchakam). We shall see one of them. 


\section{Definition}

Invariable concomitance is the nonpresence of the middle term in the locus of the nonexistence of the major term.

If we consider the statement

The hill is full of fire because it is full of smoke. In this smoke is the middle term $(R)$ and fire $(P)$ is the major term.

$$
\{\text { fire, smoke }\} \subset\{\text { fire }\} \subset\{\text { nofire, nosmoke }\}
$$

\section{$4.3 \quad$ Navya-Nyaya}

Though Nyaya and Vaisesika are separate systems, they have more similarities than dissimilarities. The later Nyaya school called, Navya-Nyaya (NN) developed as a result of blending of the two.

As an example, let us examine the following from the work of Viswanatha NyayaPancanana (1634 A.D.). He belonged to the Navadvipa School of Bengal. He is credited with the Vaisesika treatise, Bhasa-Pariccheda, and the book on logic, Siddhanta Muktavali.

Matter (Padartha) has seven categories: substance (dravya), quality (guna), action (karma), generality (samanya), particularity (visesa), inherence (samavaya), and nonexistence (abhava). This belong to visaya kanda of Vaisesika system.

Substance is composed of five elements, earth (ksiti), water (apa), light (tejas), air (marut), and ether (vyoma), space (dik), time (kala), mind (manas) and soul (atma).

Soul (atma) possesses intellect (buddhi) which comprises of apprehension or understanding (anubhuti) and remembrance or memory (smrti).

Understanding is due to perception (pratyaksa), inference (anumana), comparison (upamana) and verbal testimony (sabda). This belongs to Jnana kanda of Nyaya.

The Tarka-samgraha of Annambhatta is the most popular introductory work on the Nyaya-Vaisesika system of Indian philosophy. A native of Andhra, he flourished in 17 th century (Virupakshananda 1980).

Mullatti (1977) represents the Navya-Nyaya theory of inference in terms of contemporary logic framework. He observes that the NN theory is couched in terms of cognitions rather than premises. So the theory demands adequate sentences ( $p r a-$ mana vakya). These must satisfy four criteria: expectancy (akanksa), competency (yogyata), proximity (sannidhi) and speaker's intention (tatparya). In the sentence, "Bring a cow", the use of bring is said to raise an expectancy in the listener. A sentence such as "Bring triangularity" does not fulfil this requirement. The stock examples in the case of competency are:

1. jalena sincati "(He) wets (the ground) with water."

2. agnina sincati "(He) wets (the ground) with fire."

While both are syntactically sound, only the first is semantically sound. It is sufficient, if the sentence is sound. It need not be true. The NN theory does not also accept unexampled terms such as "barren woman's son" (vandhya-suta), "hare's horn" (sasa-srnga), and "sky-flower" (gagana-kusuma). Proximity refers to the ambiguity caused by word order. For example, observe the English sentences.

1. I saw a girl in the park with a telescope. 
2. I saw a girl in the park with a dog.

3. I saw a girl in the park with a statue.

Probably these mean respectively,

1. I saw with a telescope a girl in the park.

2. I saw a girl with a dog in the park.

3. I saw a girl in the park with a statue.

The intention (tatparya) comes into play when we talk of a word like "door". The word "close" or "open" should be supplied to find the intention of the speaker.

\section{Truth}

Indian philosophers maintain that there are truths beyond man's normal experience. Neither sense perception nor inference can impart knowledge of suprasensible facts. e.g. God, soul, their relation, soul's journey after death, heaven, hell, merit and demerit accruing from righteous and unrighteous deeds. How does one go beyond the truths that are beyond the range of the senses and reasoning?

In Vedic view, the cosmic order is controlled by a fundamental principle or truth called Rta. As stated in the Rg-Veda, the whole universe is founded on Rta and moves in it. Because of Rta, fire burns, wind blows, water flows, plants grow, humans beings think and seasons revolve. Untruth is unrta. The word satya for truth is often used in the restricted context of right speech.

The validity of the Vedic testimony is due to the fact that it discloses truths which can neither be contradicted nor established by any other means (Satprakashananda 1965).

Karl Popper's dictum clarifies the diffrence between truth and certainty: "We must distinguish between TRUTH, which is objective and absolute and CERTAINTY, which is subjective."

All elements of a knowledge base are thus uncertain to a more or less degree as these refer to chunks of human expert knowledge. On the other hand in logic, one is traditionally concerned with truth. In a propositional logic system, one should be able to identify a proposition as TRUE or FALSE. Examples of propositions are:

1. Panini is a grammarian.

2. Annambhatta is the author of Tarka Samgraha.

3. If $2+2=6$, then I am prime minister of India.

4. The present king of India is bald.

5. Rama is tall.

While it is easy to associate truth values to propositions 1 and 2 above, the truth of a compound proposition like 3 is to be derived while proposition 4 poses more problems. Truth itself may be a matter of degree, as in proposition 5 . Truth may often have to be established by combining unreliable evidences given by multiple 
sources. Logic as a tool of knowledge representation and reasoning and handling of uncertainties in knowledge are topics currently researched actively in Artificial Intelligence.

To illustrate the diffrence between truth and belief let us present the experience of Brancazio (1994):

A Moslem student noted that Quran clearly states that Jesus Christ was not crucified. This, of course. provided considerable protest from Christian students. They were surprised to learn that outside of the gospels, there is no independent secular histrorical record on the trial or crucifixion of Jesus. What was one to conclude? Or, to state the question dramatically, what is truth?

It is necessary to talk about two theories of the nature of truth. The correspondence theory claims that a statement is true if it corresponds to objective reality. The coherence theory holds that a statement is true if it is consistent with other true statements in a self-consistent system of ideas and concepts. It can be argued that the correspondence theory of truth is the model used by science (physical sciences) whereas the religious truth follows the coherence theory in the sense that a statement is true if it is consistent with the belief system of a religious community. It is interesting to note that the coherence theory of truth is the model used by mathematicians and logicians.

For the author who is neither a Moslem nor a Christian, it is sensible to assume that Jesus was either crucified or was not with a certainty factor 0.5 based on equal positive and negative evidence. Others might fall back on the coherence theory and state that crucifixion is true in the Christian world while it is not true in the Moslem world.

\section{Knowledge representation and Sanskrit}

Computer processing of natural languages, as opposed to artificial languages such as Fortran, Pascal and $\mathrm{C}$ used for writing computer programs, is an active area in Artificial Intelligence. It is now understood that this is an extremely difficult task. It has now been well recognized that Panini's Sanskrit grammar Astadhyayi presents a framework for a universal grammar of any language. This rule and meta rule based grammar uses ideas of recursion almost twenty centuries before the idea of a computer program. Its equivalence to the powerful knowledge representation structures such as semantic nets have been recognized in recent times (Briggs 1985; Kak 1987). In particular, the similarities between the karaka theory of Panini and the conceptual dependency and conceptual graph approaches used in Artificial Intelligence may be noted (Rich 1985).

Panini took the idea of action as described by a verb and developed the karaka theory by providing a context for action in terms of its relations to agent and situation.

\begin{tabular}{|l|l|}
\hline Apadana & That which is fixed when departure takes place \\
Sampradana & The recipient of the object \\
Karana & The main cause of the effect, instrument \\
Karmanana & The basis, location \\
Kartr & The object \\
\hline
\end{tabular}




\section{Concluding remarks}

In this paper, we attempted to give a flavour of classical Indian logic as it evolved over more than thirty centuries. It is interesting to know the context in which ancients viewed issues such as truth, knowledge, intelligence, cognition and language. The engineering community, of late, has started learning these concepts while attempting to design intelligent systems possessing a knowledge-base acquired from domain experts, together with the uncertainties associated with such knowledge and an inference engine performing automated reasoning. The Nyaya-Vaisesika combination is analogous to such an exercise. While most of modern research in Artificial Intelligence owes its origin to cold war and military applications, the nobler aims of the ancient scholars in acquiring knowledge may also be examined by present day scholars.

\section{References}

Brancazio P J 1994 What is truth? A course in science and religion. Am. J. Phys. 62: $893-898$

Briggs R 1985 Knowledge representation in Sanskrit and Artificial Intelligence. AI Mag. 6: 22-38

Chandra S Vidyabhusana 1970 A history of Indian logic (Delhi: Motilal Banarsidass) (First published by Calcutta University in 1921)

Kak S C 1987 The Paninian approach to natural language processing. Int. J. Approximale Reasoning 1: 117-130

Mullatti L C 1977 The Navya-Nyaya theory of inference (Dharwad: Karıatak University)

Rich E 1983 Artificial intelligence (New York: McGraw-Hill)

Satprakashananda Swami 1965 Methods of hnowledge according to Advaila Vedanta (London: George Allen \& Unwin)

Virupakshananda Swami 1980 Tarkasamgraha (with Dipika of Annambhatla) (Madras:

Sri Ramakrishna Math) 